\title{
4.8 Антикризове управління та економічна діагностика підприємства в умовах кризи
}

Проблема успішного подолання організаціями та розроблення впровадження запобіжних дій щодо кризових ситуацій завжди актуальна у всьому світі. Проблеми діагностики криз належать до малодосліджених у економічній та управлінській науці. Кризові ситуації можуть виникнути на будьякому з етапів життєвого циклу підприємства, і кожен такий випадок матиме власні унікальні особливості, що унеможливлює існування універсальної формули виходу з кризової ситуації. Особливо ця тема стала актуальною через останні події - пандемію COVID-19, підчас якої світова і національні економічні системи опинилися у зоні тривалої нестабільності.

У зв’язку із цим є гостра необхідність дослідження застосування сучасних підходів до діагностики кризових ситуацій на підприємстві, причин виникнення таких ситуацій, а також розроблення загальних шляхів виведення підприємства із кризового стану та забезпечення належного функціонування підприємства у будь-якій ситуації.

Питання управління та економічної діагностики підприємства у кризових ситуаціях знайшли відображення у працях зарубіжних учених, таких як Г. Марковіц, М. Міллер, Ф. Модільяні, П. Самуелсон, У. Шарп, Д. Тобін, Р. Солоу та ін. Вагомий внесок у дослідження теоретичних i практичних аспектів організації роботи підприємств та розроблення антикризових стратегій зробили такі вчені, як Є.М. Коротков, А.В. Волков, 3.А. Авдошина, А.Ф. Крюков та ін. Водночас дослідження із цієї тематики не вирішують проблем теоретичного і практичного обгрунтування альтернативних стратегій успішного подолання підприємствами кризисних явищ.

Будь-яке підприємство 3 моменту свого виникнення стикається із цілою низкою проблем, які можуть спровокувати гостру кризу, що супроводжується різким погіршенням показників діяльності: ліквідності, платоспроможності, рентабельності, оборотності оборотних коштів, фінансової стійкості [306, с. 139]. 
У той момент, коли підприємство починає свою діяльність, на ринку, як правило, вже діє значна кількість фірм-конкурентів. Зайняти певну нішу на ринку непросто, тому багато організацій банкрутують, не витримавши конкуренції. Але в умовах нестабільного зовнішнього середовища на рівні країни чи світу підприємство, навіть якщо воно демонструє стабільні показники зростання, може стикнутися із ситуацією, коли чинники зовнішнього середовища повністю перешкоджають його діяльності.

Саме такою ситуацією стала пандемія COVID-19, яка паралізувала більшість видів комерційної та некомерційної господарської діяльності через упровадження режиму карантину у більшості країн світу.

З 12 березня 2020 року на всій території України було запроваджено карантин та заборонено роботу суб’єктів господарювання. Це паралізувало діяльність майже усіх господарських суб’єктів у країні незалежно від виду виробництва товарів та типу послуг, кількості клієнтів. Ситуації такого масштабу не були передбачені чинним законодавством, і навіть закони, прийняті для стабілізації економічної ситуації, не гарантували підтримки тисяч підприємств, які за один день залишилися без права працювати на невизначений термін. У таких випадках необхідно якнайшвидше провести діагностику організації для того, щоб визначити загальну картину стану організації та в мінімальні терміни спрогнозувати можливості настання кризи або визначити ступінь тяжкості кризи, якщо вона вже настала.

Поняття «криза» може трактуватися по-різному відносно предмету дослідження, у нашому разі найбільш підходить визначення Л. Бартона: криза це широкомасштабна непередбачувана подія, яка веде до потенційно негативних результатів і може нанести серйозної шкоди всьому підприємству.

Виникнення і розгортання системної кризи у суспільстві, вражає основні складові елементи підприємницької діяльності, призводить до нездатності самостійного відновлення стану самоокупності та загрози банкрутства унаслідок зростання заборгованості. За таких умов необхідне швидке реагування керівників (оперативна Crash-програма), ефективне антикризове управління, 
мобілізація внутрішніх ресурсів.

Дієвим засобом виходу 3 кризового стану $є$ застосування процедури антикризового управління, яка передбачає впровадження в систему підприємницької діяльності виробничо-технічних заходів, використання зовнішніх і внутрішніх резервів для відновлення прибутковості та уникнення банкрутства.

Фінансове оздоровлення як складова частина управління кризовим станом і банкрутством включає цільовий вибір найбільш ефективних засобів, стратегії, тактики, необхідних для певного підприємства. Індивідуальність вибору цих засобів не означає, що немає деяких узагальнених, характерних для всіх підприємств, що знаходяться у фінансовій кризі. Вивчення досвіду подолання кризових ситуацій багатьох країн $\mathrm{i}$ конкретних підприємств дозволяє сформувати гнучку систему антикризового управління.

Особливо актуальним $\epsilon$ поетапний аналіз виробничо-господарських результатів діяльності підприємства та фінансово-економічного механізму антикризових перетворень на підприємстві, а також виявлення резервів і методів підвищення прибутковості та ліквідності підприємства.

Система антикризового управління підприємством являє собою комплекс узгоджених елементів, які, взаємодіючи між собою, діагностують ознаки та прояви кризи, сприяють іï подоланню, подальшому поверненню підприємницьких структур до стабільного функціонування та створюють необхідні умови для подолання негативного впливу зовнішніх та внутрішніх факторів на діяльність підприємств. До складових елементів антикризового управління належать: суб'єкт та об'єкт, мета, пріоритетні цілі та завдання, основні принципи, функції, методи та критерії оцінки ефективності проведення антикризових заходів [304, с. 51].

Головною метою антикризового управління $є$ створення умов для стійкого функціонування підприємств на ринку у відповідь на будь-які економічні, політичні і соціальні перетворення в країні, розробка стратегічних альтернатив на основі прогнозування та передбачення розвитку ситуації, уникнення 
фінансових проблем та подолання загрози банкрутства з найменшими втратами, впровадження інноваційних змін у діяльність (рис. 1).

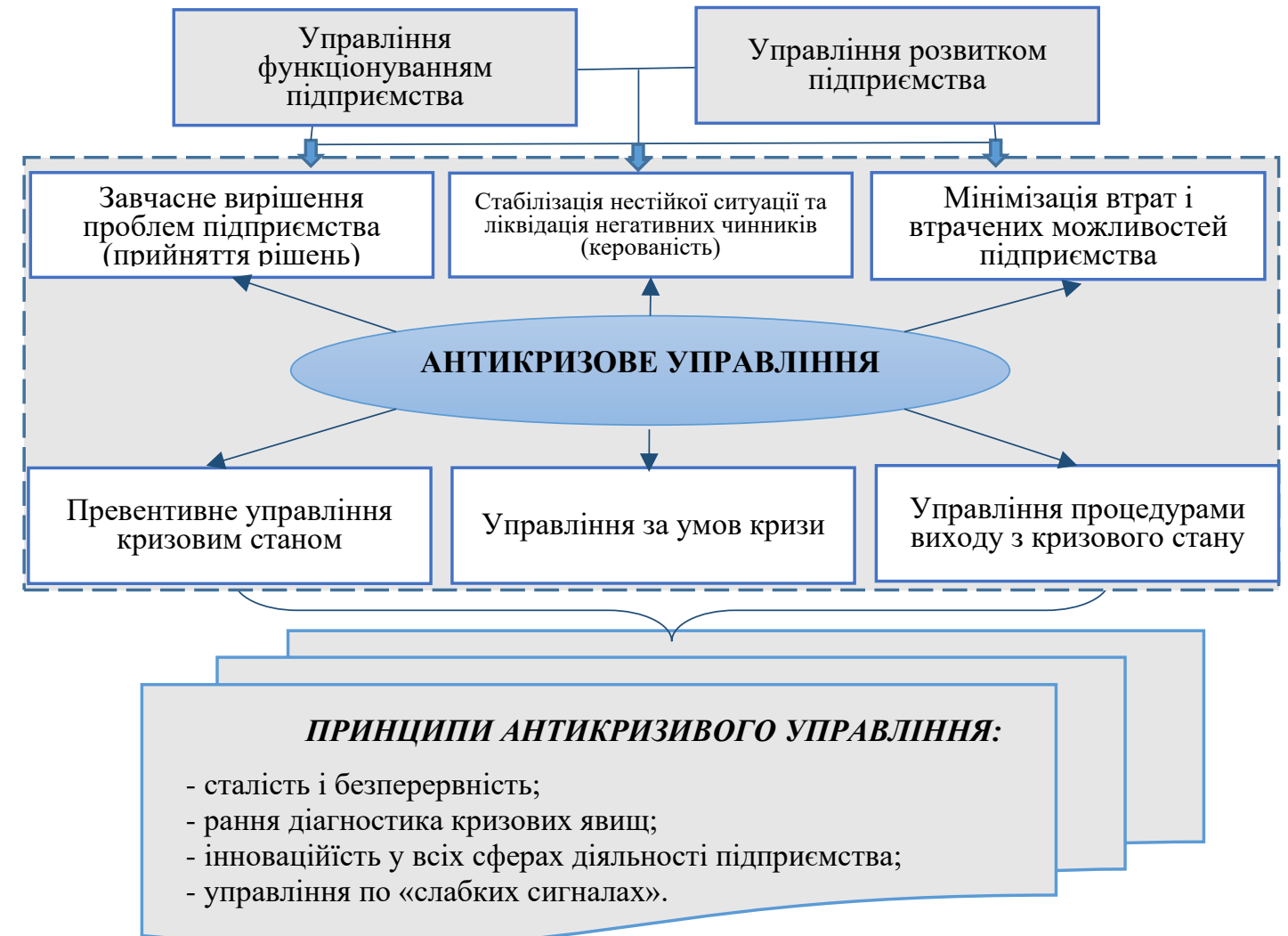

Рис.1. Сутність антикризового управління діяльністю підприємств

При попередженні кризових ситуацій, виділяють шість основних антикризових функцій: планування, організація, мотивація, облік, аналіз і контроль.

Критеріями оцінки ефективності антикризового управління є наступні:

- зміна показників виробничої діяльності та фінансового стану внаслідок антикризового управління;

- динаміка позитивних змін та економічного ефекту;

- відповідність змін втраченим можливостям підприємства;

- швидкість пристосування підприємства до змін;

- достатність та швидкість одержання інформації для прийняття об'єктивних антикризових рішень;

- доцільність антикризових заходів;

- рівень кваліфікації працівників [306, с. 115].

Аналітичне (діагностичне) дослідження підприємства, що передує 
антикризовому управлінню, повинно проводитися також під час його здійснення i є необхідним для встановлення та ідентифікації кризи, ії глибини та характеру, прийняття антикризових рішень задля виведення підприємства із стану кризи. Діагностика кризового стану є необхідним етапом у процесі вивчення небезпек, що приховані у підсистемах життєдіяльності підприємства, що здійснюється на основі дослідження проблеми у результаті нагляду за станом усіх ланок підприємства. Діагностикою кризи являється виявлення невідповідностей та характеру відхилень між фактичним та плановим (нормативним) значенням певних фінансових та економічних показників, між внутрішнім та зовнішнім середовищем підприємства, між окремими структурами всередині підприємства, аналіз величини цих відхилень та можливості їх негативного впливу на процес функціонування та розвитку підприємства.

Економічна діагностика передбачає не тільки вивчення попереднього та поточного стану підприємства, а й здійснює дослідження перспективного можливого виникнення певних ситуацій, ендогенних та екзогенних факторів, що впливають на підприємство. Також інформація, отримана у результаті діагностики, має важливе практичне значення - у результаті іiі одержання менеджери підприємства здатні, опираючись на ii дані, обгрунтувати відповідні рішення і впровадити заходи щодо зміни системи управління, фінансового оздоровлення (економічної санації), підвищення прибутковості, платоспроможності, конкурентоспроможності та ринкової привабливості підприємства [305, с. 63].

Основною метою діагностики ознак кризи на підприємстві є підготовка інформації для аналізу та первинна їі обробка задля здійснення відповідних рішень щодо управління підприємством, у тому числі й антикризового, протягом усього етапу життєдіяльності підприємства залежно від характеру отримуваної інформації. Результати економічної діагностики базуються відповідно на аналізі поточної діяльності підприємства, превентивної (попередньої) інформації та перспективного аналізу результатів виробничо-господарської та фінансової діяльності підприємства та впливають на програму розвитку підприємства та 
його стратегічний вибір. Різновидність діагностики кризового стану підприємства схематично відображена на рисунку 2.

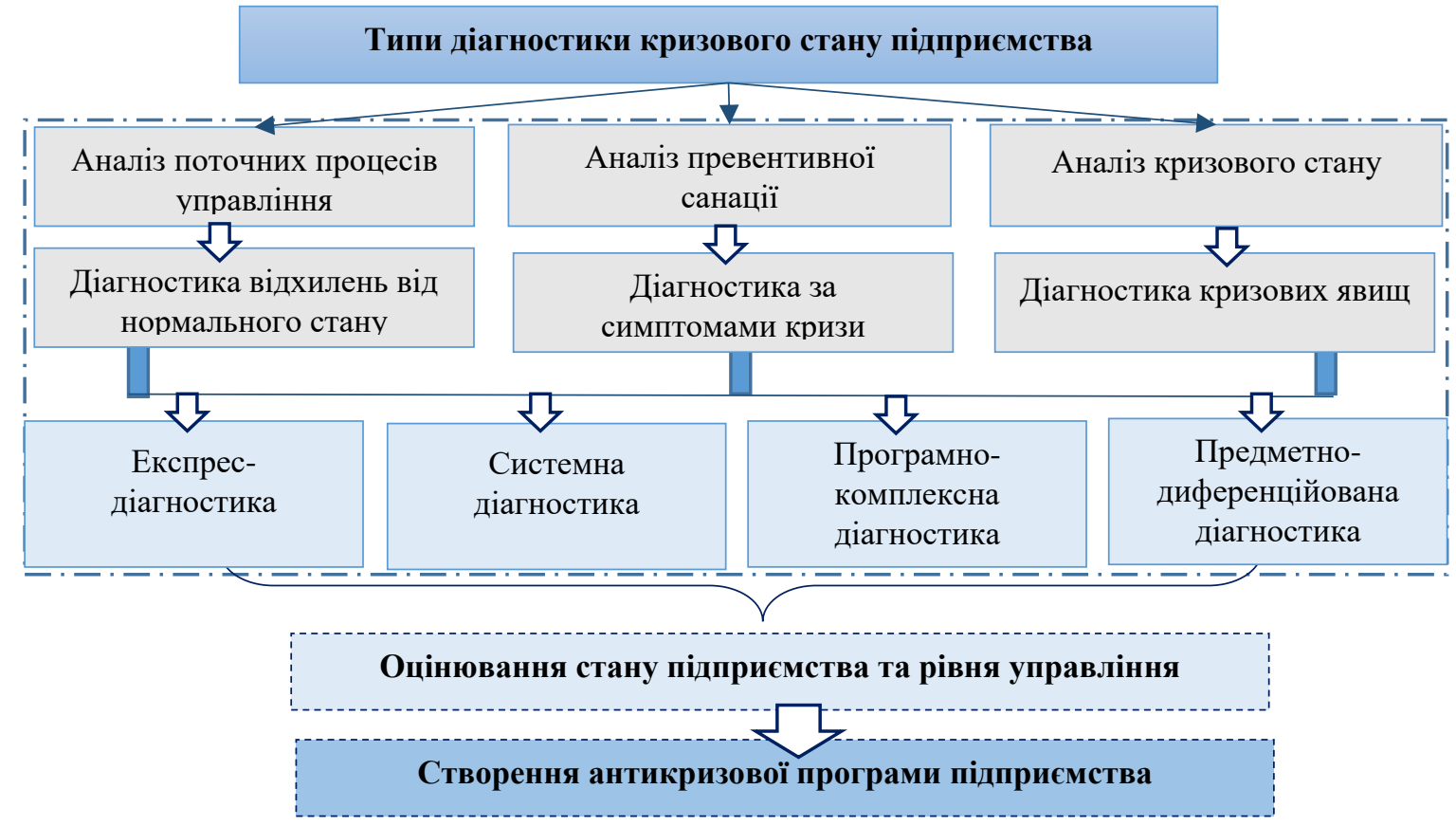

Рис. 2. Типи діагностики кризового стану підприємства

Діагностика та аналіз кризи на підприємстві залежить від фази прояву кризи. На передкризовому етапі здійснюється базовий (фундаментальний) аналіз можливості виникнення кризових явищ, що включає використання моделей та показників ймовірності банкрутства (мето Альтмана, метод Бівера, модель Аароні-Джонса-Сворі та ін.), методів оцінки ризиків (метод Монте-Карло, аналіз сценаріїв, метод критичних значень, метод експертних оцінок, метод дерева рішень), аналізу перспектив виникнення криз у галузі, аналізу портфельних активів [304].

На фазі «збурення» кризи проводиться аналіз відповідності проведених антикризових заходів характеру кризи: аналіз ефективності господарської діяльності у порівнянні із середньоринковим значенням. Аналіз ефективності диференціації портфелю активів, аналіз виробничо-технічних показників підприємства, аналіз відповідності витрат обсягу виробництва та прибутку.

Під час етапу «розгону» кризи слід звернутися до таких методів діагностики кризового стану: використання ймовірнісних методів оцінки ризику (метод аналогій, аналіз чутливості, аналіз сценаріїв), альтернативний аналіз 
короткострокових перспектив кризи в галузі з використанням технічного аналізу фондового ринку.

За умов, коли підприємство знаходиться в «апогеї» кризи, аналіз його стану на основі поточних антикризових заходів проводиться за такими методами: експрес-аналіз фінансових коефіцієнтів (ліквідності, фінансової стійкості, ділової активності, прибутковості), аналіз із використанням моделідіаграми "DU PONT", аналіз динаміки кризи у галузі та технічний аналіз фондового ринку.

Повернення до нормального стану функціонування підприємства також містить приховані ризики, тому на цьому етапі слід здійснювати короткостроковий аналіз динаміки негативних проявів та середньостроковий прогноз шляхом аналізу фінансових коефіцієнтів, аналізу та оцінювання ризиків, експрес-аналізу ефективності господарської діяльності, порівняння із конкурентами та середнім значенням по ринку.

На етапі «заспокоєння» кризи застосовується фундаментальний аналіз втрачених можливостей, у тому числі поглиблений аналіз ефективності господарської діяльності, використання ймовірнісних методів оцінки ризику, оцінювання впливу несистематичних ризиків.

Післякризовий стан підприємства потребує постійного моніторингу за його станом та діагностику можливих загроз, комплексного аналізу розмірів збитків та збереження потенціалу шляхом аналізу техніко-організаційного рівня та умов виробництва, аналізу використання виробничих ресурсів, аналізу перспектив кризи у галузі, використання глобальних узагальнених показників ймовірності банкрутства, оцінки бізнесу та операційної діяльності [308, с. 89].

Отже, на тлі світової нестабільності ситуація суб'єктів економічних відносин загострюється непідготовленістю їх до кризи. Вагомого значення для підприємств набуває антикризове управління, яке повинно бути направлено як на недопущення виникнення кризи, мінімізації їі впливу, так і на посткризову стабілізацію діяльності. Зарубіжній практиці антикризового регулювання та інституту банкрутства притаманне акцентування на комунікаціях, інноваційних 
i соціальних аспектах, тобто першочерговим i пріоритетним у процесі оздоровлення стану підприємства виступає відновлення платоспроможності суб'єктів господарювання, збереження робочих місць. Саме тому спрямованість на досягнення стратегічних завдань, своєчасне реагування за «слабкими сигналами», інноваційна політика, адекватне державне i законодавче регулювання процедур банкрутства та санації є особливо важливими при виході підприємств з кризового стану. 